\title{
STUDI TRANSPOR SENYAWA FENOL MENGGUNAKAN MEMBRAN CAIR POLIEUGENOL DENGAN PELARUT DIKLOROMETANA
}

\author{
Mamay Maslahat $^{1}$, Agung Abadi Kiswandono ${ }^{2}$ \\ ${ }^{1}$ Jurusan Kimia, Fakultas MIPA, Universitas Nusa Bangsa Bogor \\ Jl. Sholeh Iskandar KM 4 Cimanggu Tanah sareal Bogor, 16166, Indonesia \\ ${ }^{2}$ Jurusan Kesehatan Masyarakat, Fakultas Kesehatan Masyarakat \\ Universitas Prima Indonesia, Jl. Ayahanda No. 1 Medan, Indonesia \\ ${ }^{1}$ Email : maykulsum@yahoo.co.id
}

\begin{abstract}
Study on Phenol Compound Transport using Polieugenol Liquid Membrane with Dichloromrthane Solven
\end{abstract}

\begin{abstract}
Phenol is a component in waste water that is very dangerous, because it is toxic, corosif on skins and carcinogenics. It can be separated by using liquid membranes. Membrane can be a very specific filter. Liquid membrans transport technique used three phase. The phase are donor phase that contain substance to be separated, membrane phase that contains ligan in the organic solvents, and aceptore phase that contain base as release agent of ligans complex. Polyeugenol have a condition as a ligan that is capable as selective chelate agent for phenol coumpounds. In this research, polieugenol were used with dichloromethane solvents as a membrane for separating and transporting phenol separated, $\mathrm{NaOH}$ as release phase with variating $\mathrm{pHs}$, concentrations of release phase, transport time and membrane concentrations. The result showed that liquid membrane of polieugenol in dichloromethane solvent can transport phenol at source phase pH 6.5, at optimum released concentration was $0.75 \mathrm{M}$, optimum transport times was 72 hours, and optimum membran concentrations was $1,5 \times 10^{-3}$ with \% transport was $65.2 \%$.
\end{abstract}

Keywords : Liquid membrane, polyeugenol, dichlorometane, phenol

\begin{abstract}
ABSTRAK
Fenol merupakan salah satu komponen dalam air limbah yang sangat berbahaya, karena beracun dan bersifat korosif terhadap kulit serta karsinogenik. Fenol dapat dipisahkan dengan menggunakan membran cair. Membran dapat bertindak sebagai filter yang sangat spesifik. Teknik transpor membran cair melibatkan tiga fasa yaitu fasa donor, mengandung bahan yang akan dipisahkan, fasa membran berisi ligan dalam pelarut organik dan fasa akseptor yang berisi basa sebagai agen pelepas dari kompleks ligan.Polieugenol mempunyai syarat sebagai ligan sehingga mampu berfungsi sebagai agen pengkhelat yang selektif untuk senyawa fenol. Pada penelitian ini digunakan polieugenol dengan pelarut diklorometana sebagai membran untuk pemisahan dan transpor senyawa fenol, dan $\mathrm{NaOH}$ sebagai fasa pelucut dengan memvariasikan $\mathrm{pH}$, konsentrasi fasa pelucut, waktu transpor dan konsentrasi membran. Hasil penelitian menunjukan bahwa membran cair polieugenol dalam pelarut diklorometana dapat mentranspor fenol pada $\mathrm{pH}$ fasa sumber optimum 6,5, pada konsentrasi pelucut optimum $0,75 \mathrm{M}$, waktu transpor optimum $72 \mathrm{jam}$, dan pada konsentrasi membran optimum $1,5 \times 10^{-3}$ dengan $\%$ transpor $65,2 \%$.
\end{abstract}

Kata kunci : membran cair, polieugenol, diklorometana, fenol

\section{PENDAHULUAN}

Teknologi membran telah berkembang dengan pesat dalam beberapa dekade terakhir ini karena memiliki berbagai keunggulan baik secara teknik maupun secara ekonomi, sehingga sering kali digunakan dalam proses-proses pemisahan maupun pemurnian baik untuk skala industri maupun penelitian di laboratorium. Keunggulan tersebut dikarenakan dalam pemisahan dengan membran tidak membutuhkan zat kimia tambahan dan juga kebutuhan energinya 
sangat minimum, sederhana, praktis dan mudah dilakukan.

Perkembangan sektor industri yang cukup pesat menimbulkan masalah lingkungan yang cukup serius, diantaranya adalah limbah senyawa fenol. Fenol merupakan salah satu komponen dalam air limbah yang sangat berbahaya, karena beracun dan bersifat korosif terhadap kulit serta karsinogenik, oleh karena itu fenol digolongkan sebagai bahan beracun dan berbahaya (B3). US EPA mengkategorikan fenol dalam daftar prioritas senyawa toksik pencemar daerah perairan (Mortaheb et.al, 2008).

Limbah senyawa fenol dihasilkan dari limbah cair industri mikroelektronik, industri minyak dan gas, tekstil, kertas, otomotif, dan pabrik bahan kimia. fiberglass, pulp kertas, perekat, kayu lapis, farmasi, cat, tekstil, keramik, plastik, formaldehid dan sebagainya. Senyawa fenol bila mencemari perairan dapat menimbulkan rasa dan bau tidak sedap dan pada konsentrasi nilai tertentu akan menyebabkan kematian organisma di perairan. Senyawa fenol dapat mengalami bioakumulasi dan biomagnifikasi oleh organisme perairan (akuatik), fenol dapat masuk ke dalam tubuh melalui air minum dan makanan yang berasal dari organisme akuatik.

Disamping kerugian yang ditimbulkan, fenol merupakan senyawa yang memiliki banyak kegunaan, misalnya sebagai bahan perekat kayu lapis, antiseptik, bahan anestetika oral dan obat obatan, sehingga pemulihan fenol dari air limbah merupakan hal yang menarik. Proses penanggulangan dan penanganan limbah industri dalam bentuk senyawa organik fenol menjadi bagian yang sangat penting untuk melindungi dan melestarikan lingkungan, karena limbah yang timbul dapat mengakibatkan pencemaran apabila dibuang begitu saja sebelum mengalami pengolahan.

Polutan di daerah perairan, termasuk fenol dapat dihilangkan dengan beberapa teknik, di antaranya adalah adsorpsi. Moval (2004) telah memisahan fenol dari air limbah menggunakan batubara muda (lignitic coals) dengan rendemen 43\% - 60\% (Mulder, 1996), Maroof (2005) juga telah memisahkan fenol menggunakan metode adsorbsi modifikasi Montmorillonite (Swain et.al, 2007), tetapi teknik tersebut umumnya tidak ekonomis karena membutuhkan bahan serta energi yang besar (Swain et.al, 2007).

Cara lain memisahkan fenol adalah dengan membran cair. Membran dapat bertindak sebagai filter yang sangat spesifik. Hanya molekul-molekul dengan ukuran tertentu yang bisa melewati membran sedangkan sisanya akan tertahan dipermukaan membran. Drapala et al. (2001) menggunakan membran cair untuk ekstraksi peptida, Titus et al. (2005) untuk Ektrasi $17 \beta$-estradiol dari ginjal, Susu, dan urin (Titus at. all. 2006). Garea et.al. (1983), Cichy \& Szymanowski (2002) dapat memisahan senyawa fenol dengan metode SLM menggunakan campuran kerosin dan cyanex 923 , sedangkan hasil eksperimen Kusumastuti (2007) menunjukkan bahwa lebih dari $90 \%$ fenol dapat dipulihkan dari air limbah dengan menggunakan membran cair emulsi.

Sistem transpor melalui membran cair organik dapat digunakan untuk memisahkan senyawa organik yang sulit dicapai dengan metode lain dan untuk pengayaan atau pengambilan ulang. Transpor fenol melalui membran cair memainkan peranan yang penting di dalam menirukan fungsi membran biologi dan tekhnologi pemisahan, karena metode ini mempunyai selektivitas dan efisiensi yang tinggi, mengurangi penggunaan jumlah pelarut dan pemisahan sejumlah ion dapat dilakukan secara kontinyu dalam satu unit operasi.

Teknik transpor membran cair melibatkan tiga fasa yaitu fasa donor, mengandung bahan yang akan dipisahkan, fasa membran berisi ligan dalam pelarut organik dan fasa akseptor yang berisi basa sebagai agen pelepas dari kompleks ligan. Syarat ligan yang dapat digunakan pada fasa membran yaitu mempunyai berat molekul yang tinggi, bersifat lipofilik dan mempunyai struktur yang memungkinkan terjadinya pembentukan kompleks. Salah satu bahan alam yang potensial untuk 
dikembangkan menjadi suatu jenis ligan yaitu eugenol.

Eugenol merupakan salah satu komponen kimia yang terdapat dalam minyak daun cengkeh. Eugenol dalam daun cengkeh ini dapat digunakan sebagai bahan awal sintesis suatu senyawa karena mengandung tiga gugus fungsional yaitu gugus alil, eter, dan fenol (Anwar, 1994), oleh karena itu eugenol dapat dipolimerisasi menjadi polieugenol. Polieugenol yang terbentuk ini mempunyai syarat sebagai ligan sehingga diharapkan mampu berfungsi sebagai agen pengkhelat yang selektif dan sama-sama memiliki gugus benzen, sehingga ligan ini dapat digunakan sebagai ligan transpor selektif untuk senyawa fenol. Berdasarkan uraian tersebut, maka dalam penelitian ini akan digunakan metode membran cair, yaitu polieugenol sebagai membran untuk pemisahan dan transpor senyawa fenol dan $\mathrm{NaOH}$ 0,1 M sebagai pelucut.

\section{METODE PENELITIAN}

\section{Penentuan panjang gelombang maksimum dan kalibrasi fenol}

Sederet gelas kimia $50 \mathrm{~mL}$ disiapkan untuk membuat standar fenol. Larutan baku fenol (100 ppm) sebanyak 0, $1,2,3,4,5,6$, dan $7 \mathrm{~mL}$ dimasukkan ke dalam gelas kimia tersebut, lalu ditambahkan dengan akuabides sehingga total volume masing-masing adalah $10 \mathrm{~mL}$. Setelah itu ditambahkan 2,5 mL larutan $\mathrm{NH}_{4} \mathrm{OH}$ 0,5 $\mathrm{M}$ dan $\mathrm{pH}$-nya diatur antara 9,8-10,2 menggunakan buffer posfat.

Agar terjadi perubahan warna, larutan ditambahkan 1,0 mL larutan 4aminoantipirin $2 \%$ dan $1,0 \mathrm{~mL}$ larutan kalium ferrisianida $8 \%$ lalu dikocok dengan segera dan didiamkan sampai terjadi perubahan warna (merah muda). Setelah terjadi perubahan warna, campuran larutan dipindahkan ke dalam corong pisah, lalu ditambahkan $10 \mathrm{~mL}$ kloroform, corong pisah dikocok $10 \mathrm{kali}$, setelah terjadi pemisahan campuran, corong pisah dikocok kembali 10 kali lalu dibiarkan campuran terpisah kembali. Setelah terjadi pemisahan, lapisan kloroform dipisahkan dan disaring dengan kertas saring yang berisi $\mathrm{Na}_{2} \mathrm{SO}_{4}$.

Dengan menggunakan ekstrak kloroform dari blangko, spektrofotometer UV-Vis (Spektronik 20D+ 333183) di nol kan, lalu absorbansi salah satu larutan diukur pada $\lambda$ (panjang gelombang) 370 $\mathrm{nm}$ sampai $600 \mathrm{~nm}$ untuk mencari atau mendapatkan panjang gelombang maksimum. Kemudian masing-masing larutan diukur absorbansinya pada $\lambda$ maksimum tersebut untuk membuat kurva kalibrasi. Nilai absorbansi yang dihasilkan kemudian dibuat kurva standar, yakni absorbansi versus ppm fenol. Sebagai perbandingan panjang gelombang maksimum, juga diukur dengan menggunakan UV-Vis (Shimadzu), yaitu blangko dan larutan fenol 60 ppm.

\section{Penentuan kadar fenol dalam sampel}

Sampel dari fasa sumber dan fasa pelucut diambil masing-masing $9 \mathrm{~mL}$ lalu dimasukkan ke dalam gelas kimia $50 \mathrm{~mL}$, Akuabides sebanyak $9 \mathrm{~mL}$ disediakan juga sebagai blanko, kemudian masing-masing larutan ditambahkan $2,5 \mathrm{~mL} \mathrm{NH}_{4} \mathrm{OH} 0,5$ $\mathrm{M}$ dan diatur pH-nya antara 9,8 - 10,2 dengan buffer fospat. Campuran dipindahkan ke dalam corong pisah dan ditambahkan 1,0 $\mathrm{mL}$ larutan 4aminoantipirin $2 \%$ dan $1,0 \mathrm{~mL}$ larutan kalium ferrisianida $8 \%$, lalu dikocok dengan segera, lalu campuran didiamkan sampai terjadi pewarnaan (merah muda).

Setelah terjadi perubahan warna, campuran larutan dipindahkan ke dalam corong pisah, lalu ditambahkan $9 \mathrm{~mL}$ kloroform, corong pisah dikocok 10 kali, kemudian setelah terjadi pemisahan, corong pisah dikocok kembali 10 kali lalu dibiarkan campuran terpisah. Setelah terjadi pemisahan, lapisan kloroform dipisahkan dan disaring dengan kertas saring yang berisi $\mathrm{Na}_{2} \mathrm{SO}_{4}$.

$$
\text { Spektrofotometer }
$$

UV-Vis (Spektronik 20D+ 333183) di nol kan pada $\lambda$ maksimum hasil dari prosedur 5.2.1 dengan menggunakan ekstrak kloroform dari blangko. Absorbansi dari ekstrak masing-masing sampel diukur pada $\lambda$ maksimum, kemudian besarnya 
konsentrasi fenol diperoleh dari persamaan pada kurva standar.

Transpor fenol dengan variasi $\mathrm{pH}$ fasa sumber pada konsentrasi polieugenol $1 \times 10^{-3} \mathrm{M}$ dalam diklorometana

Polieugenol $1 \times 10^{-3} \quad \mathrm{M}$ dalam pelarut diklorometana sebanyak $5,0 \mathrm{~mL}$ ditempatkan dalam pipa $\mathrm{U}$, kemudian ditambahkan 10,0 mL larutan fenol sebagai fasa sumber dengan konsentrasi $60 \mathrm{ppm}$ dengan variasi $\mathrm{pH}$ yaitu pada $\mathrm{pH} 3,5 ; 4,5$; 5,$5 ; 6,5$ dan 8,0. Masing-masing variasi $\mathrm{pH}$ dibuat pengulangannya sebanyak tiga larutan (triplikat) dan ditambahkan 10,0 $\mathrm{mL} \mathrm{NaOH} 0,5 \mathrm{M}$ sebagai fasa pelucut.

Pipa U ditutup lalu diaduk selama 24 jam pada suhu kamar. Setelah selesai diaduk, larutan dipisahkan antara fasa sumber dan fasa pelucut dengan menggunakan pipet tetes. Konsentrasi fenol yang terdapat di dalam fasa sumber dan fasa pelucut dianalisis dengan metode spektrofotometer UV-Vis.

\section{Transpor fenol dengan variasi konsentrasi pelucut pada konsentrasi polieugenol $1 \times 10^{3} \mathrm{M}$ dalam diklorometana pada $\mathrm{pH}$ fasa sumber optimum}

Polieugenol $1 \times 10^{-3} \quad \mathrm{M}$ dalam pelarut diklorometana dengan volume 5,0 $\mathrm{mL}$ ditempatkan dalam pipa $\mathrm{U}$, kemudian ditambahkan 10,0 mL larutan fenol sebagai fasa sumber dengan konsentrasi $60 \mathrm{ppm}$ pada $\mathrm{pH}$ optimum dan ditambahkan 10,0 $\mathrm{mL} \mathrm{NaOH}$ sebagai fasa pelucut dengan variasi konsentrasi 0,$10 ; 0,25 ; 0,50$ dan 0,$75 ; 1.0$ M. Masing-masing variasi konsentrasi dibuat pengulangannya sebanyak tiga larutan (triplikat).

Pipa U ditutup lalu diaduk selama 24 jam pada suhu kamar. Setelah selesai diaduk larutan dipisahkan antara fasa organik, fasa sumber dan fasa pelucut dengan menggunakan pipet tetes. Konsentrasi fenol yang terdapat di dalam fasa sumber dan fasa pelucut dianalisis dengan menggunakan spektrofotometer UV-Vis.
Transpor fenol dengan variasi waktu transpor pada konsentrasi polieugenol $1 \times 10^{-3} \mathrm{M}$ dalam diklorometana pada $\mathrm{pH}$ fasa sumber dan konsentrasi pelucut optimum

Polieugenol $1 \times 10^{-3} \quad \mathrm{M}$ dalam pelarut diklorometana dengan volume optimum ditempatkan dalam pipa $U$, kemudian ditambahkan 10,0 mL larutan fenol sebagai fasa sumber dengan konsentrasi $60 \mathrm{ppm}$ pada $\mathrm{pH}$ optimum dan ditambahkan 10,0 $\mathrm{mL} \mathrm{NaOH}$ sebagai fasa pelucut pada konsentrasi optimum.

Pipa U ditutup lalu diaduk dengan variasi waktu transpor selama $6,16,24$, 48 dan 72 jam pada suhu kamar. Masingmasing variasi waktu transpor dibuat pengulangannya sebanyak tiga larutan (triplikat). Setelah selesai diaduk larutan dipisahkan antara fasa organik, fasa sumber dan fasa pelucut dengan menggunakan pipet tetes. Konsentrasi fenol yang terdapat di dalam fasa sumber dan fasa pelucut dianalisis dengan menggunakan spektrofotometer UV-Vis.

\section{Transpor fenol dengan variasi konsentrasi membran dalam diklorometana pada pH fasa sumber, konsentrasi pelucut dan waktu transpor optimum}

Polieugenol dengan konsentrasi $0 \times 10^{-4}, 5 \times 10^{-4}, 10 \times 10^{-4}, 15 \times 10^{-4}$ dan $20 \times 10^{-4} \quad \mathrm{M}$ dalam pelarut diklorometana dengan volume $5 \mathrm{~mL}$ ditempatkan dalam pipa $\mathrm{U}$, kemudian ditambahkan $10,0 \mathrm{~mL}$ larutan fenol dengan konsentrasi $60 \mathrm{ppm}$ pada $\mathrm{pH}$ optimum dan ditambahkan 10,0 $\mathrm{mL} \mathrm{NaOH}$ sebagai fasa pelucut pada konsentrasi optimum, Pipa U ditutup lalu diaduk pada suhu kamar dengan waktu optimum. Setelah selesai diaduk larutan dipisahkan antara fasa organik, fasa sumber, dan fasa pelucut dengan menggunakan pipet tetes. Konsentrasi fenol yang terdapat di dalam fasa sumber dan fasa pelucut dianalisis dengan menggunakan spektrofotometer Uv-vis. 
HASIL DAN PEMBAHASAN

\section{Penentuan $\lambda_{\text {maks }}$ dan Pembuatan Kurva Standar}

Hasil penentuan panjang gelombang maksimum untuk fenol menggunakan spektrofotometer UV-Vis spektronik 20D adalah $455 \mathrm{~nm}$, sedangkan menggunakan spektrofotometer UV-Vis Shimadzu adalah $454 \mathrm{~nm}$. Lamda $455 \mathrm{~nm}$ ini digunakan untuk pengukuran Konsentrasi fenol selanjutnya.

\section{Pengaruh pH Fasa Sumber Terhadap Transpor Fenol}

Suatu proses transpor fenol menggunakan membran cair dipengaruhi oleh keasaman atau $\mathrm{pH}$ suatu larutan. $\mathrm{pH}$ merupakan parameter keasaman yang sangat penting dalam proses transpor, karena perubahan keasaman dapat menyebabkan perubahan laju transpor. Hasil pengamatan pengaruh $\mathrm{pH}$ fasa sumber disajikan pada Tabel 1 .

Tabel 1 menunjukkan bahwa terjadi perubahan jumlah fenol yang tertranspor terhadap variasi $\mathrm{pH}$. Dari hasil perhitungan dapat diketahui bahwa $\mathrm{pH}$ berpengaruh terhadap \% Cp. Hal ini dapat dilihat dari hubungan antara \% $\mathrm{Cp}$ dengan $\mathrm{pH}$ fasa sumber hasil penelitian, yang ditunjukkan pada Gambar 1.

Tabel 1. Data Pengaruh pH Fasa Sumber terhadap Transpor Fenol

\begin{tabular}{|c|c|c|c|c|c|c|}
\hline \multirow{2}{*}{ pH Fenol } & \multicolumn{3}{|c|}{ Ppm } & \multirow{2}{*}{$\% \mathrm{C}_{\mathrm{p}}$} & \multirow{2}{*}{$\% \mathrm{C}_{\mathrm{s}}$} & \multirow{2}{*}{$\% \mathrm{C}_{\mathrm{m}}$} \\
\hline & FS & FP & Total & & & \\
\hline 3.5 & 38.1 & 16.5 & 54.6 & 27.5 & 63.5 & 9.0 \\
\hline 4.5 & 35.3 & 15.8 & 51.1 & 26.3 & 58.9 & 14.8 \\
\hline 5.5 & 37.7 & 16.7 & 54.4 & 27.9 & 62.8 & 9.3 \\
\hline 6.5 & 36.3 & 18.6 & 54.9 & 31.0 & 60.5 & 8.5 \\
\hline 8.0 & 34.5 & 17.3 & 51.8 & 28.8 & 57.6 & 13.7 \\
\hline
\end{tabular}

Keterangan :

$\begin{array}{ll}\mathrm{FS} & : \text { Fasa Sumber } \\ \mathrm{FP} & : \text { Fasa Pelucut } \\ \% \mathrm{C}_{\mathrm{p}} & : \% \text { transpor fasa pelucut } \\ \% \mathrm{C}_{\mathrm{s}} & : \% \text { transpor fasa sumber } \\ \% \mathrm{C}_{\mathrm{m}} & : \% \text { transpor fasa membran }\end{array}$

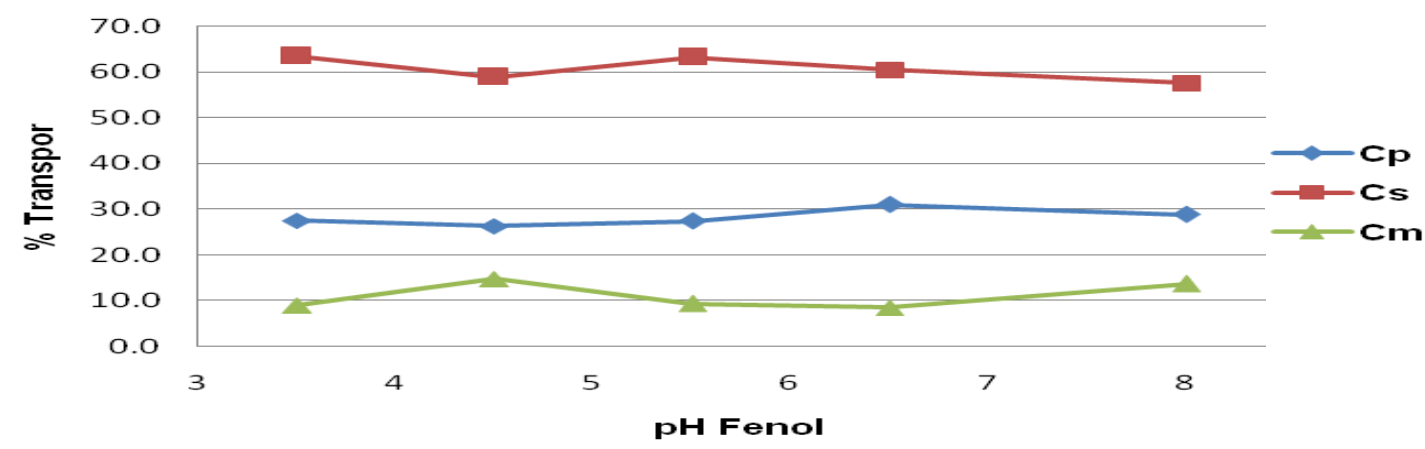

Gambar 1. Hubungan Antara \% Transpor Fenol dengan pH Fasa Sumber 
Hasil penelitian menunjukkan bahwa efisiensi fenol mulai tertranspor pada $\mathrm{pH}$ 3,5 dengan persen transpor sebesar 27,5\%. Besarnya fenol yang tertranspor pada awalnya menunjukkan penurunan, yaitu dari $27,5 \%$ menjadi 26,3\% pada $\mathrm{pH} 4,5$. Tetapi jika dilihat pada fasa membran terdapat $14,8 \%$ fenol yang masih terikat dengan membran, artinya ada $14,8 \%$ fenol yang siap untuk dilepaskan ke fasa pelucut, dan jika dijumlahkan antara fasa membran dan fasa pelucut akan didapatkan persen transpor sebesar $41,1 \%$. Nilai ini lebih besar jika dibandingkan pada $\mathrm{pH} 3,5$.

Menurut Kiswandono (2010),
bahwa mekanisme transpor fenol menggunakan membran cair polieugenol adalah melalui interaksi $\pi$ dan ikatan hidrogen. Pada saat $\mathrm{pH}$ 4,5 fenol sudah dilepas dari fasa sumber tetapi belum sampai pada fasa pelucut, karena masih terikat oleh ikatan hidrogen dan interkasi $\pi$, akibatnya persen transpor pada fasa pelucut kecil (Canet dan Seta, 2001). Gambar 2 memperlihatkan bahwa $\mathrm{pH}$ optimum untuk transpor fenol adalah pada $\mathrm{pH}$ 6,5 yang menghasilkan \% transpor sebesar 31,0\%, hal ini dikarenakan $\mathrm{pH}$ fenol hampir mendekati netral. Kondisi $\mathrm{pH}$ fenol mempengaruhi efisiensi pemisahan dan proses transpor, $\mathrm{pH}$ asam akan menyebabkan rendahnya efisiensi transpor dan proses pemisahan, dalam hal ini transpor akan lebih efisien apabila solut (fenol) yang akan ditranspor dinetralkan terlebih dahulu ( Park et al., 2006).

Pada Gambar 2 diketahui bahwa hasil transpor fenol dipengaruhi oleh $\mathrm{pH}$ larutan. Secara umum, meningkatnya transpor fenol-polieugenol sejalan dengan meningkatnya $\mathrm{pH}$ terbatas pada kisaran $\mathrm{pH}$ tertentu. Pada $\mathrm{pH}$ yang lebih tinggi jumlah fenol dalam sistem meningkat sehingga terjadi kompetisi ion hidroksida dengan membran cair polieugenol dalam berikatan dengan fenol, akibatnya jumlah fenol yang terkonversi menjadi sodium fenolat menjadi berkurang sehingga fenol tertranspor oleh polieugenol menjadi berkurang.

\section{Pengaruh Konsentrasi Pelucut Terhadap Transpor Fenol}

Transpor fenol melalui membran dapat juga terjadi melalui mekanisme transpor akibat gradien konsentrasi (perbedaan konsentrasi) fenol pada fasa sumber dan fasa pelucut. Transpor balik fenol ke fasa membran dicegah dengan menambahkan stripping agent $(\mathrm{NaOH})$ ke dalam fasa pelucut. Stripping agent bekerja mengkonversi fenol menjadi senyawa turunannya, yaitu sodium fenolat dan menjebak senyawa tersebut dalam fasa pelucut sehingga tidak kembali ke fasa membran (1). Laju transpor dapat dipertahankan karena masih terjadi gradien konsentrasi antara fasa sumber dan fasa pelucut.

Hasil pengamatan pengaruh konsentrasi pelucut, yaitu $\mathrm{NaOH}$ pada proses transpor dapat dilihat pada Tabel 2 dan Gambar 3.

Hasil penelitian menunjukkan, bahwa semakin tinggi konsentrasi $\mathrm{NaOH}$ sebagai fasa pelucut, maka akan semakin tinggipersen transpor fenol $(\% \mathrm{Cp})$ dan optimum pada konsentrasi $\mathrm{NaOH} \mathrm{0,75} \mathrm{M,}$ sedangkan di atas konsentrasi tersebut menunjukkan penurunan persen transpor fenol. Hal ini dikarenakan larutan $\mathrm{NaOH}$ sampai dengan konsentrasi $0,75 \mathrm{M}$ dalam keadaan pekat sehingga sifat basanya lebih besar, maka proses pelepasan garam kation di antarmuka fasa membran-akseptor akan cepat sehingga jumlah fenol yang tertranspor semakin banyak. Tetapi kepekatan ini tidak berlaku untuk konsentrasi $\mathrm{NaOH} \quad 1,0 \quad \mathrm{M}$, hal ini dikarenakan banyaknya fenol yang tertranspor jauh lebih sedikit dibandingkan konsentrasi $\mathrm{NaOH}$ yang ada, sehingga natrium fenolat yang terbentuk tidak sebanding dengan ion natrium yang ada.

Gambar 3 menunjukkan bahwa terjadi perubahan jumlah fenol yang tertranspor terhadap variasi konsentrasi pelucut dan polieugenol dapat secara efektif mentranspor fenol dari fasa sumber ke fasa membran dan melepaskannya ke fasa pelucut. Fenol mengalami transpor dalam jumlah maksimum pada konsentrasi 
pelucut sebesar 0,75 M yang menghasilkan harga \% transpor sebesar 40,7\%.
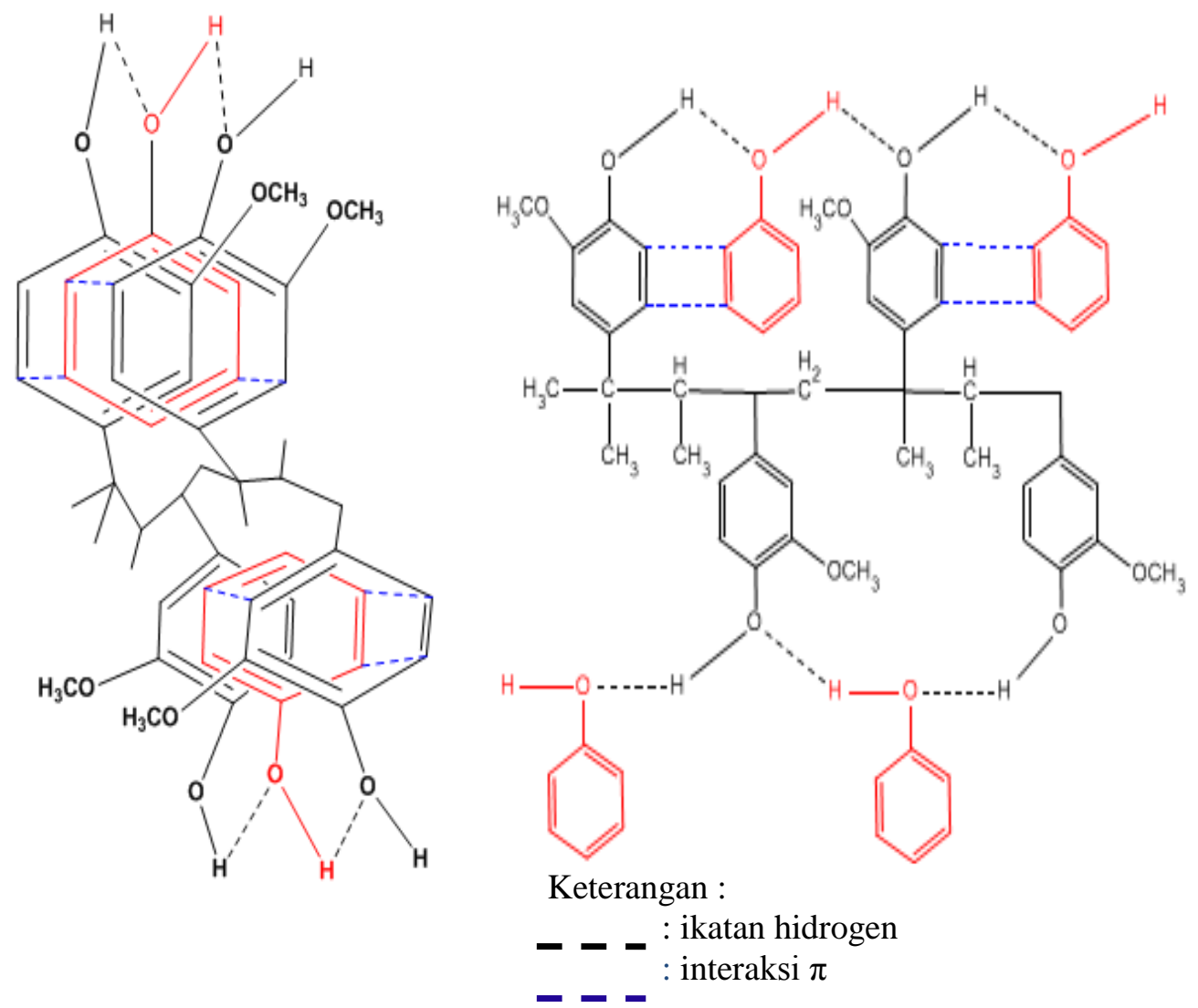

Gambar 2. Interaksi Antara Polieugenol dan Fenol Karena Adanya Ikatan Hidrogen dan Interaksi $\pi$ (Kiswandono, 2010)

Tabel 2. Data Pengaruh Konsentrasi Pelucut terhadap Transpor Fenol

\begin{tabular}{ccccccc}
\hline \multirow{2}{*}{$\begin{array}{c}\text { Konst. NaOH } \\
(\mathrm{M})\end{array}$} & \multicolumn{3}{c}{ Ppm } & \multirow{2}{*}{$\% \mathrm{C}_{\mathrm{p}}$} & \multirow{2}{*}{$\% \mathrm{C}_{\mathrm{s}}$} & \multirow{2}{*}{$\% \mathrm{C}_{\mathrm{m}}$} \\
\cline { 2 - 3 } & $\mathrm{FS}$ & $\mathrm{FP}$ & Total & & 57.2 & 17.7 \\
0.10 & 34.3 & 15.0 & 49.4 & 25.0 & 57.3 & 16.4 \\
0.25 & 33.2 & 17.0 & 50.2 & 28.4 & 55.3 & 12.0 \\
0.50 & 34.0 & 18.7 & 52.8 & 31.2 & 56.7 & 11.8 \\
0.75 & 28.5 & 24.4 & 52.9 & 40.7 & 47.5 & 18.9 \\
1.00 & 27.5 & 21.2 & 48.7 & 35.3 & 45.8 & 18.9 \\
\hline
\end{tabular}

Keterangan :

FS : Fasa Sumber

FP : Fasa Pelucut

$\% \mathrm{Cp}: \%$ transpor fasa pelucut

$\% \mathrm{Cs}: \%$ transpor fasa sumber

$\% \mathrm{Cm}: \%$ transpor fasa membran 


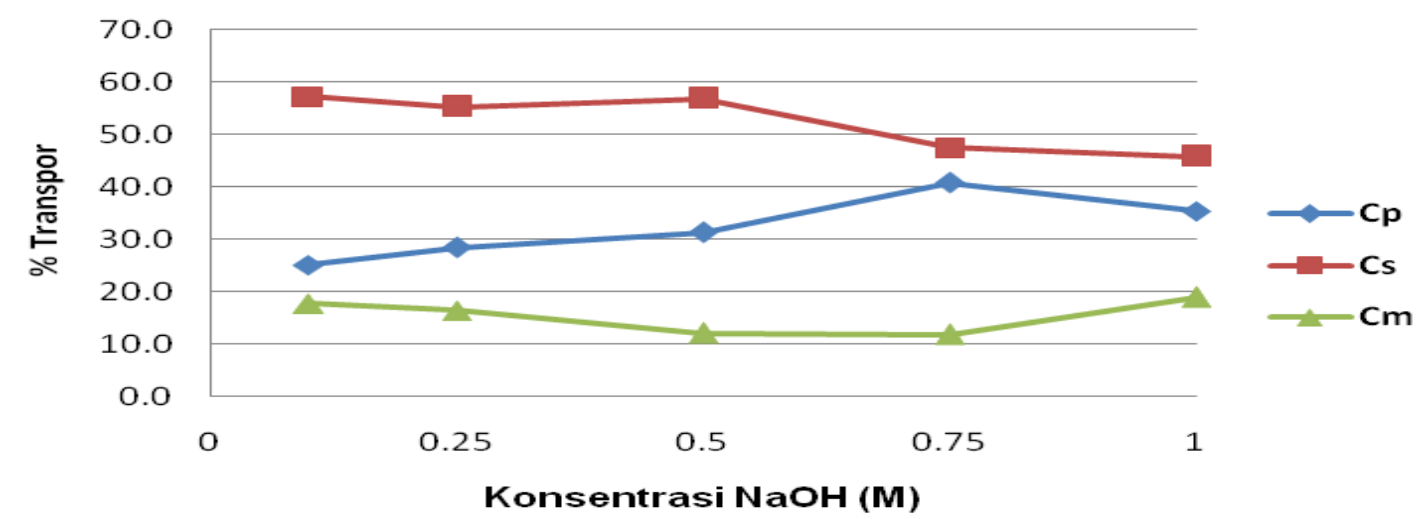

Gambar 3. Hubungan aAntara \% Transpor Fenol dengan Konsentrasi $\mathrm{NaOH}$ sebagai Fasa Pelucut

Tabel 3. Data Pengaruh Waktu Transpor terhadap Transpor Fenol

\begin{tabular}{|c|c|c|c|c|c|c|}
\hline \multirow{2}{*}{ Waktu (jam) } & \multicolumn{3}{|c|}{$\mathrm{Ppm}$} & \multirow{2}{*}{$\% \mathrm{Cp}$} & \multirow[b]{2}{*}{$\% \mathrm{Cs}$} & \multirow[b]{2}{*}{$\% \mathrm{Cm}$} \\
\hline & FS & $\mathrm{FP}$ & Total & & & \\
\hline 6 & 41.1 & 5.8 & 46.9 & 9.7 & 68.4 & 21.8 \\
\hline 16 & 36.3 & 16.5 & 52.8 & 27.6 & 60.5 & 11.9 \\
\hline 24 & 26.7 & 23.6 & 50.3 & 39.4 & 44.5 & 16.1 \\
\hline 48 & 19.8 & 32.3 & 52.1 & 53.8 & 33.0 & 13.2 \\
\hline 72 & 24.5 & 32.9 & 57.4 & 54.8 & 40.9 & 4.3 \\
\hline
\end{tabular}

Keterangan :

FS : Fasa Sumber

FP : Fasa Pelucut

$\% \mathrm{Cp}: \%$ transpor fasa pelucut

$\% \mathrm{Cs}: \%$ transpor fasa sumber

$\% \mathrm{Cm}: \%$ transpor fasa membran

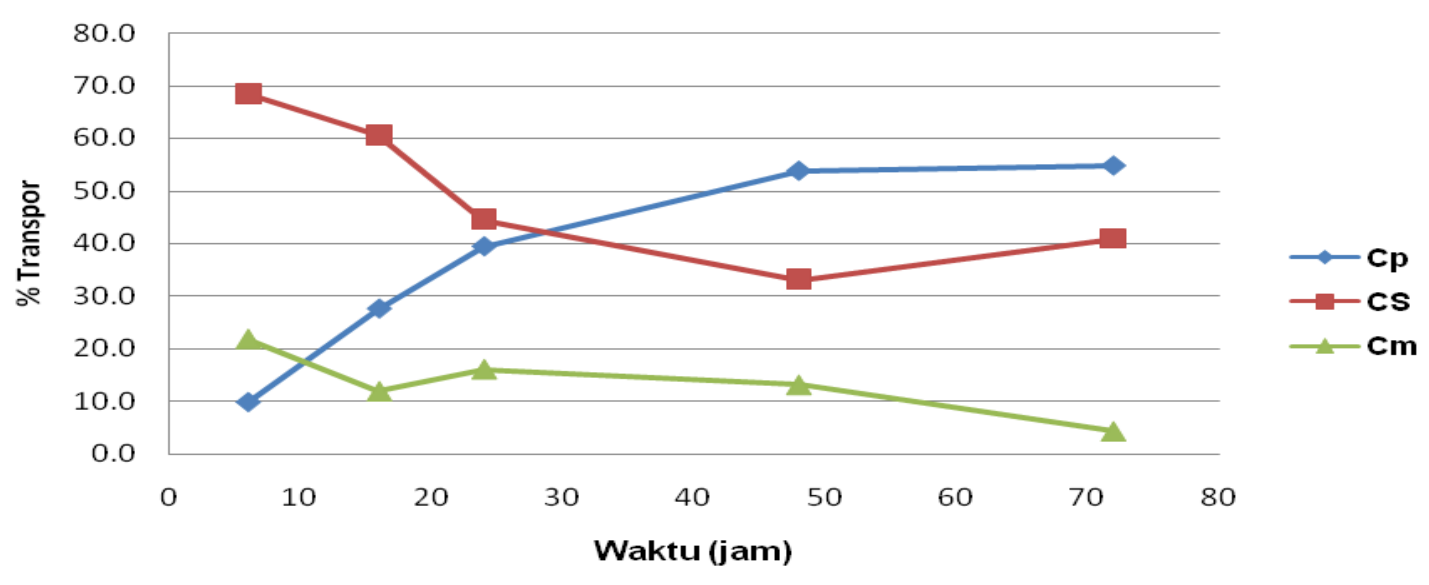

Gambar 4. Hubungan Antara \% Transpor Fenol dengan Waktu Transpor 


\section{Pengaruh Waktu Terhadap Ttranspor Fenol}

Hasil pengamatan pengaruh waktu transpor dapat dilihat pada Tabel 3 dan Gambar 4.

Hasil penelitian menunjukkan, bahwa waktu transpor berpengaruh terhadap \%Cp. Tabel 3 memperlihatkan bahwa semakin meningkatnya waktu transpor maka jumlah fenol yang tetranspor akan semakin besar. Hal ini dikarenakan semakin lama waktu transpor, maka waktu terjadinya kontak antara fenol, membran dan pelucut semakin lama, kemungkinan terbentuknya interaksi antara fenol dan membran semakin besar yang diimbangi dengan semakin cepatnya pelepasan fenol ke fasa pelucut, sehingga semakin banyak fenol dari fasa sumber yang tertranspor ke dalam fasa pelucut. Hal ini dapat dilihat dari hubungan antara $\% \mathrm{Cp}$ dengan waktu transpor yang ditunjukkan pada Gambar 4.Gambar 4 menunjukkan bahwa terjadi perubahan jumlah fenol yang tertranspor terhadap variasi waktu transpor dan membran polieugenol dapat secara efektif mentranspor fenol dari fasa sumber ke fasa membran dan melepaskannya ke fasa pelucut. Fenol mengalami transpor dalam jumlah maksimum pada saat transpor selama 72 jam yang menghasilkan harga $\%$ Cp sebesar $54,8 \%$.

Pada waktu 72 jam semua fenol dapat mencapai persen transpor yang maksimum. Sedangkan pada waktu kurang dari 72 jam, semua fenol yang tertranspor belum optimal karena waktu transpor yang dibutuhkan masih kurang. Dengan adanya peningkatan lamanya waktu transpor maka laju transpor akan semakin bertambah sehingga persentase fenol yang tertranspor akan semakin besar. Gambar 4 juga menunjukkan, bahwa pada saat waktu transpor selama 6 jam, fenol telah tertranspor sebanyak $9,7 \%$. Hal ini dapat diartikan, bahwa pada waktu 6 jam tersebut telah terjadi interaksi antara fenol dengan polieugenol yang kemudian dikonversi oleh fasa pelucut, $\mathrm{NaOH}$ sebagai natrium fenolat.
Dari grafik juga terlihat bahwa pada saat transpor berlangsung selama 48 jam ke 72 jam peningkatan jumlah fenol yang tertranspor tidak terlalu signifikan sehingga dapat dikatakan bahwa pada saat transpor berlangsung selama 48 jam ligan sudah mulai jenuh dan jumlah fenol yang tertranspor sudah mulai mencapai maksimum. Jika transpor dilanjutkan dengan waktu yang lebih lama lagi, kemungkinan tidak efektif, karena fenol yang tertranspor relatif sangat kecil. Hal ini telah dilakukan oleh Kiswandono (2010), di mana transpor fenol menggunakan polieugenol dalam pelarut kloroform sampai 120 jam, dan kenaikan transpor hanya $\pm 1 \%$ pada 96 jam dan $0,5 \%$ pada 120 jam.

\section{Pengaruh Konsentrasi Membran Terhadap Transpor Fenol}

Hasil pengamatan pengaruh waktu transpor dapat dilihat pada Tabel 4 dan Gambar . Tabel 4 memperlihatkan, bahwa pada konsentrasi membran $0,0 \times 10^{-4} \mathrm{M}$ telah terjadi transpor fenol sebesar $38,6 \%$. Konsentrasi membran $0,0 \times 10^{-4} \mathrm{M}$ adalah sebagai kontrol, artinya bahwa membran tersebut tidak mengandung polieugenol, dengan kata lain bahwa pada fasa membran tersebut hanya berisi diklorometana saja. Fenol yang tertranspor berasal dari fenol yang larut dalam diklorometana, kemudian fenol yang larut dalam diklorometana akan melewati fasa antarmuka sumber/membran dan fasa membran/fasa pelucut lalu terkonversi menjadi natrium fenolat, tetapi fenol yang tertranspor pada membran tanpa polieugenol hanya dalam jumlah yang terbatas, karena kelarutan dalam diklorometana pada kondisi yang ada akan memerlukan waktu yang lama.

Berbeda dengan diklorometana yang mengandung polieugenol. Pada kondisi ini persen transpor fenol akan lebih besar dibandingkan dengan diklorometana yang tidak mengandung polieugenol, hal ini terjadi karena terjadi interaksi antara fenol dengan polieugenol, baik melalui ikatan hidrogen maupun oleh interaksi $\pi$ (seperti pada Gambar 2), sehingga 
membantu proses transpor fenol lebih cepat.

Tabel 4. Data pengaruh konsentrasi membran terhadap transpor fenol

\begin{tabular}{|c|c|c|c|c|c|c|}
\hline \multirow{2}{*}{$\begin{array}{l}\text { Konst. Membran. } \\
\times 10^{-4}(\mathrm{M})\end{array}$} & \multicolumn{3}{|l|}{ Ppm } & \multirow{2}{*}{$\% \mathrm{C}_{\mathrm{p}}$} & \multirow{2}{*}{$\% \mathrm{C}_{\mathrm{s}}$} & \multirow{2}{*}{$\% \mathrm{C}_{\mathrm{m}}$} \\
\hline & FS & FP & Total & & & \\
\hline 0.0 & 27.2 & 23.2 & 50.4 & 38.6 & 45.4 & 16.0 \\
\hline 5.0 & 24.4 & 26.0 & 50.3 & 43.3 & 40.6 & 16.1 \\
\hline 10.0 & 24.5 & 32.9 & 57.4 & 54.8 & 40.9 & 4.3 \\
\hline 15.0 & 15.2 & 39.1 & 54.3 & 65.2 & 25.4 & 9.5 \\
\hline 20.0 & 16.4 & 35.5 & 51.9 & 59.1 & 27.3 & 13.6 \\
\hline
\end{tabular}

Keterangan :

FS : Fasa Sumber

FP : Fasa Pelucut

$\% \mathrm{Cp}: \%$ transpor fasa pelucut

$\% \mathrm{Cs}: \%$ transpor fasa sumber

$\% \mathrm{Cm}: \%$ transpor fasa membran

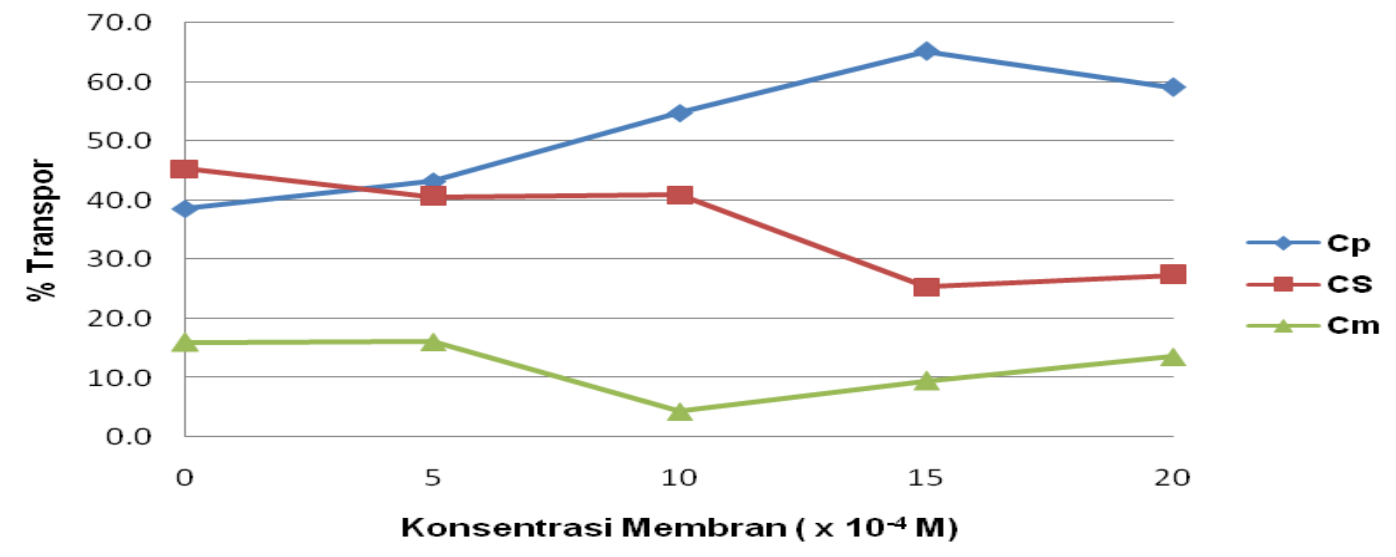

Gambar 5. Hubungan antara \% transpor fenol dengan konsentrasi membran

Gambar 5 memperlihatkan bahwa semakin meningkatnya konsentrasi polieugenol akan menyebabkan kenaikan jumlah fenol yang tertranspor. Hal ini disebabkan oleh jumlah partikel polieugenol yang meningkat, artinya sisi aktif $-\mathrm{OH}$ dan cincin benzena semakin banyak sehingga interaksi fenolpolieugenol melalui ikatan hidrogen dan interaksi $\pi$ semakin banyak. Tetapi semakin banyak jumlah mol polieugenol justru menurunkan transpor fenol. Hal ini dikarenakan sisi aktif dari polieugenol sangat banyak, sehingga tidak sebanding dengan jumlah partikel fenol, akibatnya sisi aktif tersebut justru saling menutupi. Hal lain, akan terjadi kompetisi antara polieugenol yang jumlahnya tidak sebanding dengan jumlah fenol yang ada, sehingga kemungkinan fenol berinteraksi dengan sisi aktif polieugenol menjadi kecil, yang pada akhirnya berdampak terhadap berkurangnya jumlah fenol yang tertranspor.

Gambar hubungan antara \% transpor dengan konsentrasi membran 
menunjukkan bahwa terjadi perubahan jumlah fenol yang tertranspor terhadap variasi konsentrasi membran dan membran polieugenol dapat secara efektif mentranspor fenol dari fasa sumber ke fasa membran dan melepaskannya ke fasa pelucut. Dari Gambar 5 dapat kita lihat bahwa fenol tertranspor maksimum pada saat menggunakan konsentrasi membran $15 \times 10^{-4} \mathrm{M}$ yang menghasilkan $\%$ transpor optimum sebesar $65,2 \%$.

\section{KESIMPULAN}

Berdasarkan hasil penelitian, maka dapat disimpulkan bahwa membran cair polieugenol dalam pelarut diklorometana dapat mentranspor fenol pada $\mathrm{pH}$ fasa sumber optimum 6,5, pada konsentrasi pelucut optimum $0,75 \mathrm{M}$, waktu transpor optimum 72 jam, dan pada konsentrasi membran optimum $1,5 \times 10^{-3}$ dengan $\%$ transpor $65,2 \%$.

\section{UCAPAN TERIMAKASIH}

Terimakasih kepada Dirjen DIKTI yang telah memberikan dana penelitian melalui Program Hibah Penelitian Dosen Muda Tahun 2010, serta Bapak Dr. Dwi Iswanta, Staff Dosen Kimia Fakultas MIPA Universitas Gadjah Mada.

\section{DAFTAR PUSTAKA}

Anwar, C. The Conversion of Eugenol into More Valuable Substances. Disertasi. FMIPA, Universitas Gadjah Mada, Yogyakarta, Indonesia, 1994.

Canet L, Seta P. Extraction and separation of metal cation in solution by suppoted liquid membran using lasalocid A as carrier. Pure Appl. Chem 2001; 73: 2039-2046.

Drapala A, Dzygiel P, Jonson JA, Wieczorek P. Supported liquid membran extraction of peptides. J Act Biochi Pol 2001; 48: 11131116.

Kiswandono, AA. Studi Transpor Fenol dengan Menggunakan Membran Cair polieugenol, Tesis. Universitas Gadjah Mada, Yogyakarta, 2010.

Kusumastuti A. PEMULIHAN FENOL DARI AIR LIMBAH DENGAN MEMBRAN CAIR EMULSI. Tesis Magister Teknik kimia. Master Theses from JBPTITBPP. 2007.

http://tf.lib.itb.ac.id/gdl.php?mod =browse\&op=read\&id=jbptitbpp -gdl-adhikusuma-25021 download, selasa, 20 jan 2009 jam 15.25.

Mortaheb HR, Amini MH, Sadeghian F, Mokhtarani B, Daneshyar H. Study on a new surfactant for removal of phenol from wastewater by emulsion liquid membran. Journal of Hazardous Materials 2008; 160: 582-588.

Mulder. M. Basic Principles of Membran Technology. Sec. edition. Netherland: Kluwer Academic Publisher, 1996.

Swain B, Jeong J, Lee J, Lee G. Separation of $\mathrm{Co}(\mathrm{II})$ and $\mathrm{Li}(\mathrm{I})$ by supported liquid membran using Cyanex 272 as mobile carrier. $J$ Mem Sci 2007; 297: 253-261.

Titus AMM, Nindi MM. Supported liquid membran extraction od $17 \beta$ estradiol and its metabolism in a variety of biological matrices. Afric J Biotech 2006; 5: 1827183. 